UNITED STATES

DEPARTMENT OF THE INTERIOR

GEOLOGICAL SUR VEY

APPRAISAL OF GROUND-WATER CONDITIONS AND

POTENTIAL FOR SEAWATER INTRUSION AT TAHOLAH, QUINAULT IN DIAN RESERVATION, WASHINGTON

By B. W. Drost

U.S. GEOLOGICAL SURVEY

Water-Resources Investigations

Report 84-4361

Prepared in cooperation with the

QUINAULT INDIAN NATION

Tacoma, Washington

1985 
UNITED STATES DEPARTIMENT OF THE INTERIOR

Donald P. Hodel, Secretary

GEOLOGICAL SURVEY

Dallas L. Peck, Director

For additional information write to:

District Chief

U.S. Geological Survey

1201 Pacific Avenue - Suite 600

Tacoma, Washington 98402-4384
Copies of this report

can be purchased from:

Open-File Services Section

Western Distribution Branch

U.S. Geological Survey

Box 25425, Federal Center

Lakewood, Colorado 80225

(Telephone: (303) 234-5888) 


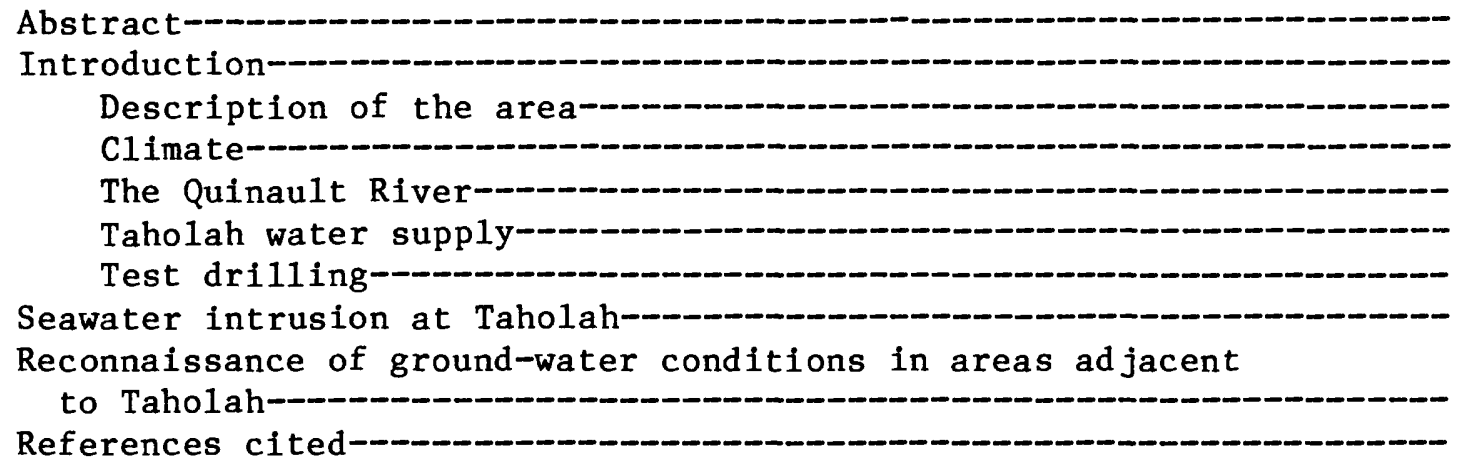

Climate-- 6

Taholah water supply-_- 9

Test drilling-_ 11

Seawater intrusion at Taholah- 12

to Taholah- of ground-water conditions in areas adjacent 14

References cited-_ 15

\section{ILLUSTRATIONS}

FIGURES 1. Map showing location of study area- 3

2. Map showing topography, well locations, and surface-water data sites-- 5

3-5. Diagrams showing schematic longitudinal profiles of the lower reach of the Quinault River with water depths and salinity values during:

3. High-tide and low-flow conditions, August 7, 1979- 7

4. Mid-tide and low-flow conditions, August 8, 1979-- 7

5. High-tide and moderate-flow conditions, November 15, 1979-- 8

6. Map showing probable configuration of the water table and generalized ground-water flow directions during high and low tides at Taholah, January 21, 1980------

\section{TABLES}

TABLE 1. Drillers' logs of wells and test holes in and adjacent to Taholah-- 16

2. Records of wells and test holes in and adjacent to Taholah-- 25

3. Water levels and specific conductances measured in USGS test holes in Taholah 


\section{WELL-N UMBERING SYSTEM}

The well numbers used in this report give the location of wells according to the official rectangular public-land survey. For example, in well number $21 / 12 \mathrm{~W}-6 \mathrm{E} 1$, the part preceding the hyphen indicates successively the township and range (T.21 N., R.12 W.) north and west of the Willamette base line and meridian, respectively. The first number following the hyphen indicates the section (sec. 6), and the letter (E) indicates the 40-acre subdivision of the section as shown in the sketch below. The last number is a sequence number used to distinguish wells in the same 40 -acre tract. Thus, well $21 / 12 \mathrm{~W}-6 \mathrm{E} 1$ is the first well inventoried in the SW $\frac{1}{4}$ of the $\mathrm{NW}_{\frac{1}{4}}$ of sec. $6, \mathrm{~T} .21 \mathrm{~N} ., \mathrm{R} .12 \mathrm{~W}$.

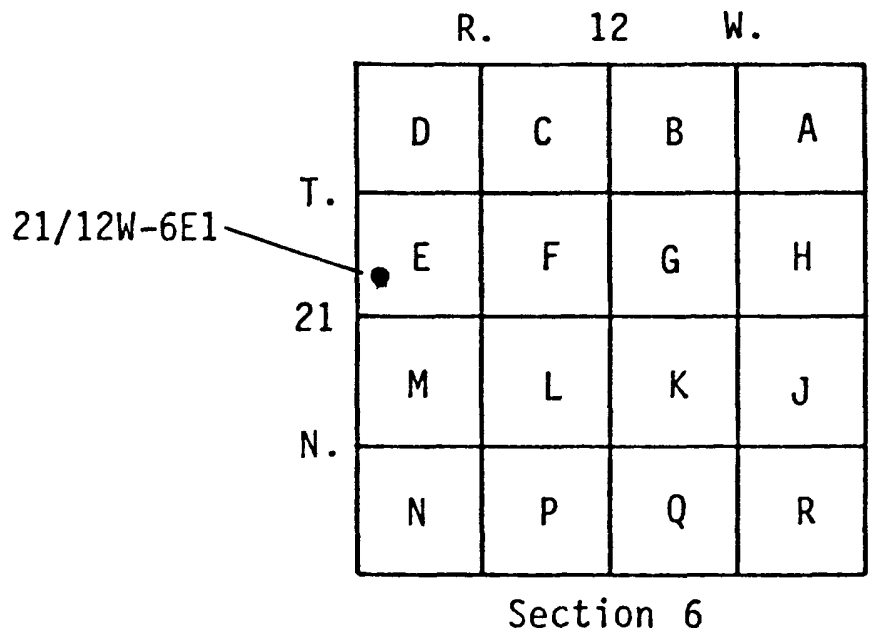


METRIC (SI) CONVERSION FACTORS

\begin{tabular}{|c|c|c|}
\hline Multiply & By & To obtain \\
\hline $\begin{array}{l}\text { inches (in.) } \\
\text { feet (ft) } \\
\text { miles (mi) } \\
\text { square miles (mi } 2) \\
\left.\text { cubic feet per second ( } \mathrm{ft}^{3} / \mathrm{s}\right) \\
\text { gallons per minute ( } \mathrm{gal} / \mathrm{min})\end{array}$ & $\begin{array}{l}2.540 \\
0.3048 \\
1.609 \\
2.59 \\
28.32 \\
0.02832 \\
0.06309\end{array}$ & $\begin{array}{l}\text { centimeters }(\mathrm{cm}) \\
\text { meters }(\mathrm{m}) \\
\text { kilometers }(\mathrm{km}) \\
\text { square kilometers }\left(\mathrm{km}^{2}\right) \\
\text { liters per second }(\mathrm{L} / \mathrm{s}) \\
\text { cubic meters per second }\left(\mathrm{m}^{3} / \mathrm{s}\right) \\
\text { liters per second }(\mathrm{L} / \mathrm{s})\end{array}$ \\
\hline $\begin{array}{l}\text { To convert degrees Celsius }\left({ }^{\circ} \mathrm{C}\right. \\
\text { equation: }{ }^{\circ} F=9 / 5^{\circ} \mathrm{C}+32\end{array}$ & degrees & Fahrenheit $\left({ }^{\circ} \mathrm{F}\right)$, use the \\
\hline
\end{tabular}




\title{
APPRAISAL OF GROUND-WATER CONDITIONS AND \\ POTENTIAL FOR SEAWATER INTRUSION AT TAHOLAH, QUINAULT INDIAN RESERVATION, WASHINGTON
}

By B. W. Drost

\begin{abstract}
The town of Taholah, situated on the Pacific Coast at the mouth of the Quinault River, will probably require a considerable increase in its supply of good-quality water due to a rapidly growing population. To provide this anticipated supply, several wells were recently drilled, but yielded water with chloride concentrations greater than 300 milligrams per liter. This exceeds the concentration ( 250 milligrams per liter) at which most people can detect a significantly salty taste.

The ground-water flow system beneath the lowland at Taholah was defined from water-level data obtained from 10 test holes. During low tide the system receives inflow from the Quinault River on the east and from the uplands on the south, and discharges water toward the ocean on the west and the Quinault River on the north. During high tide, water flows into the ground-water system along all margins of Taholah, blocking all ground-water outflow. The ground-water system undergoes these changes in inflow and outflow with each tide cycle.

Saline water from the Pacific Ocean was observed to move as far as 1.5 miles up the Quinault River during periods of combined high tide and low streamflow. However, during high tide and moderate streamflow, saline water was observed only about 0.5 mile up the river. The inflow of marine water up the Quinault River from the Pacific Ocean introduces large quantities of salty water into the ground-water system. This precludes any chance of obtaining a good-quality water supply from the ground-water system beneath Taholah.

Data from test holes drilled in the unconsolidated glacial deposits and underlying Tertiary siltstones on the margin of the upland southeast of Taholah indicate that these sources would not be adequate for the community's water needs. Farther east, how ever, coarse-grained unconsolidated materials near river level may be capable of supplying the needed water. This area of unconsolidated materials is probably above the maximum upstream extent of salty water in the Quinault River, but further study is needed to determine the obtainable yields from these materials.
\end{abstract}




\section{INTRODUCTION}

The community of Taholah, headquarters of the Quinault Indian Reservation, is situated at the mouth of the Quinault River on the west coast of the Olympic Peninsula in the State of Washington (fig. 1). With a 1979 population of about 1,200 people, the community is growing rapidly and anticipating an increasing demand for a larger supply of good-quality water for its domestic and commercial needs, which include a fish-processing plant. A steady demand of at least $300 \mathrm{gal} / \mathrm{min}$ is anticipated.

For years the water supply for the town has been obtained from several springs issuing from the lower slope of a terrace situated above the floor of the Quinault River valley, about 1 mile east of town. However, because of increased water demand by the town and decreased flow of the springs, two wells $(21 / 13-1 \mathrm{Cl}$ and 1C2) were drilled for the tribe in 1978 on the valley floor about halfway between the springs and the town. The quantity of water from the wells was adequate to supply the town, but a serious water-quality problem was noticed within a few hours after pumping began. The water had a salty taste, and testing indicated chloride concentrations in excess of $300 \mathrm{mg} / \mathrm{L}$ (milligrams per liter). Chloride concentrations in excess of $250 \mathrm{mg} / \mathrm{L}$ generally result in an unpleasant, salty taste. The springs were again used for the town's supply, with the wells used only as a backup system.

The study described in this report was made to (1) determine the source and extent of chloride in the existing well field, (2) assess the susceptibility to seawater intrusion of alternate well sites in the area, and (3) conduct a general appraisal of ground-water conditions adjacent to Taholah.

The study was carried out during the period July 1979 - January 1980 and included: (1) driling test holes and monitoring their water levels during a tidal cycle to define the shallow ground-water flow system beneath the valley floor at Taholah; (2) measuring salinity values versus depth in the Quinault River during a tidal cycle to determine the nature and extent of seawater intrusion into the estuary; (3) using (2) and (3) above to determine the source of the seawater intrusion into the ground-water system at Taholah; and (4) drilling test holes along the south side of the Quinault River valley and the edge of the upland terrace, as part of a general appraisal of ground-water conditions adjacent to Taholah. 


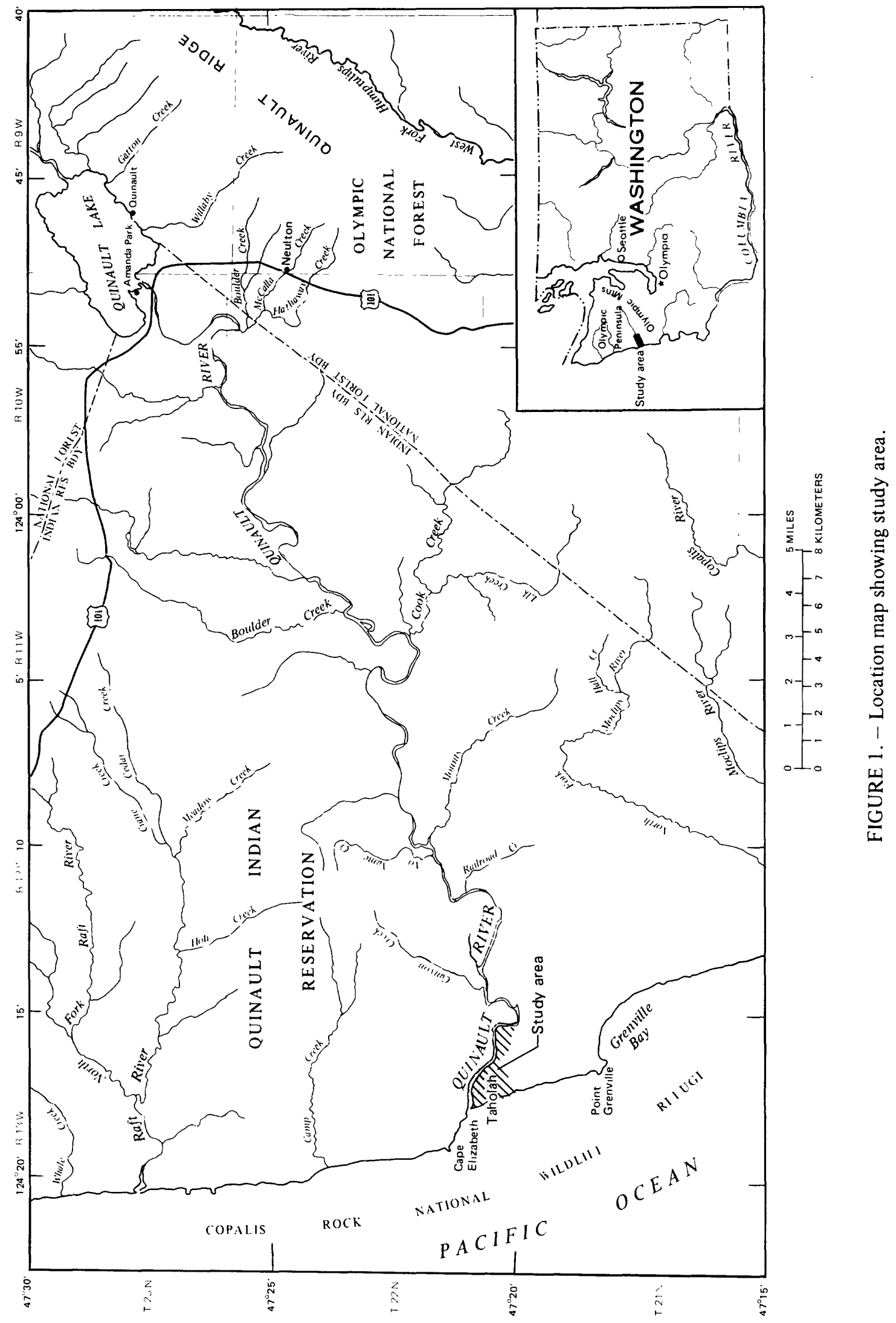




\section{Description of the Area}

The town of Taholah is situated on the floor of the Quinault River valley, south of the river near its mouth at the Pacific Ocean (fig. 1), at an altitude of 10 to 20 ft. The valley floor in the Taholah area covers about one-half of a square mile and is bounded on the north and east by the Quinault River, on the west by the Pacific Ocean, and on the south by the northern slope of an upland whose upper edge is at an altitude of about $120 \mathrm{ft}$ (fig. 2). The valley floor is underlain by unconsolidated alluvium (sand, silt, and gravel) deposited by the river. The upland terrace south and southeast of Taholah is composed of a veneer of glacial drift (till, sand, and gravel) of Pleistocene age which overlies sedimentary rock-primarily siltstone, with some sandstone and conglomerate--all of the Quinault Formation of Tertiary age (Rau, 1973 and 1975). The sedimentary rocks dip 23 to 55 degrees to the north where exposed on the terrace and may extend at similar angles beneath the Quinault River valley floor.

\section{Climate}

The study area has a maritime climate owing to the influence of the nearby Pacific Ocean. Summers are relatively cool and dry, and winters are mild and wet.

Based on precipitation data gathered at the weather station at Point Grenville, 3 miles south of Taholah, annual rainfall averages about 88 inches, and has ranged from 67 inches in 1978 to 115 inches in 1961 (U.S. Department of Commerce, 1960-73; U.S. National Oceanic and Atmospheric Administration, 1974-78). About two-thirds of the precipitation occurs during the period November-March. Some snowfall occurs in the winter and this may accumulate to depths of 4 to 6 inches.

The mean annual air temperature in the Taholah area is about $49^{\circ} \mathrm{F}$. Mean monthly temperatures are about $54^{\circ}$ to $60^{\circ} \mathrm{F}$ in summer, and about $38^{\circ}$ to $45^{\circ} \mathrm{F}$ in winter. Seldom does the temperature fall below freezing. 


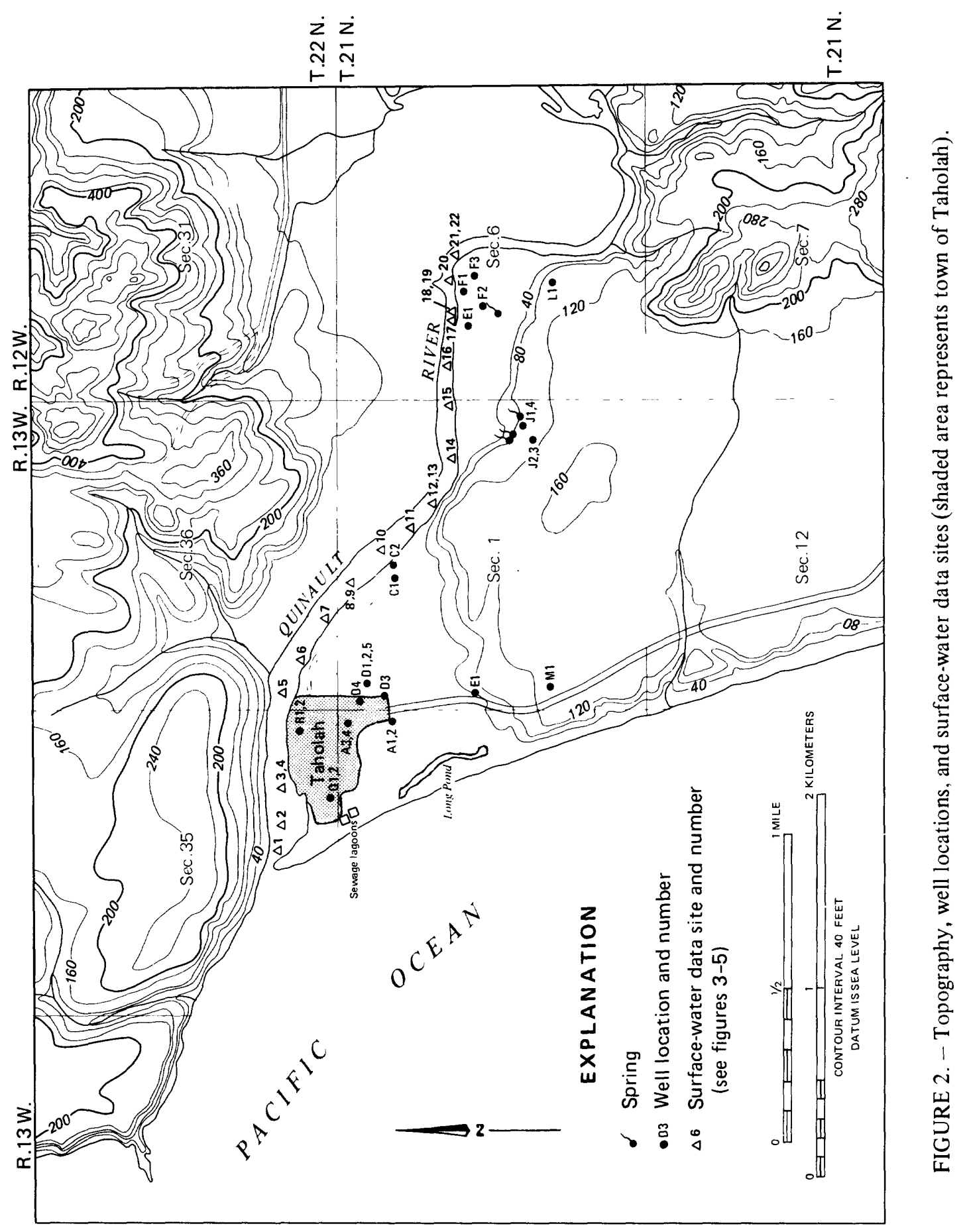




\section{The Quinault River}

The Quinault River has a drainage area of $412 \mathrm{mi}^{2}$ and heads at snowfields and glaciers in the central part of the Olympic Mountains. The nearest gaging station on the river is upstream at Quinault Lake (USGS station 12039500). There the river drains an area of $264 \mathrm{mi}^{2}$, and has an average annual discharge of $2,843 \mathrm{ft}^{3} / \mathrm{s}$, as calculated for the period 1911-78. Mean daily discharges during this 67-year period ranged from a maximum of $50,200 \mathrm{ft}^{3} / \mathrm{s}$ on November 4,1955 , to a minimum of $276 \mathrm{ft}^{3} / \mathrm{s}$ on September 12, 1944. Mean monthly discharge is greatest in January $\left(4,350 \mathrm{ft}^{3} / \mathrm{s}\right)$ and least in August $\left(954 \mathrm{ft}^{3} / \mathrm{s}\right)$. The flow of the river upstream from this gaging station is affected by natural storage in Quinault Lake. The flow of the river past Taholah is probably greater than that recorded downstream from Quinault Lake, because several tributaries that drain lowland areas contribute flow to the river between the gaging station and Taholah.

Seawater from the ocean--with a salinity of about $35 \mathrm{ppt}$ (parts per thousand) and a chloride concentration of about $19,000 \mathrm{mg} / \mathrm{L}$-intrudes into the lowermost 1.5-mile estuarine reach of the Quinault River, particularly in late summer and during periods of combined high tide and low streamflow. Measurements of salinity in this reach of the stream, during high tide and low streamflow on August 7, 1979, showed that the estuary was a modified salt-wedge type, with a layer of relatively fresh water (salinity less than $5 \mathrm{ppt}$ ) overlying a layer of saline water (salinity equal to or greater than $5 \mathrm{ppt}$ ). When averaged over a tidal cycle, water movement in the upper layer is seaward, but in the lower layer it is in the upstream direction. Because the channel bottom is irregular and water depths vary markedly from place to place along the monitored reach, the salty layer is not continuous or of equal thickness-several pockets of salty water occur between shallow reaches of relatively fresh water, even during periods of lower tide. Figures 3-5 show schematic longitudinal profiles for various dates and hydrologic conditions along the monitored reach of the river, with the values of salinity recorded at various sites and depths. Locations of data points are shown in figure 2.

The Quinault River narrows (fig. 2) and deepens (fig. 3) about 1,000 ft upstream of the general location of wells $21 / 13-1 \mathrm{Cl}$ and $1 \mathrm{C} 2$. At sites 12 and 13, high salinity readings indicated that seawater had migrated upstream of these wells during high tide on August 7, 1979 (fig. 3). Additional salinity measurements made on August 8 at about mid-tide, but following a low tide, showed that seawater still existed in the deeper pockets of the channel (fig. 4). This suggests that during late summer and early fall, when streamflow is relatively low, the deeper parts of the estuary probably contain salty water for periods of at least several weeks during low-flow periods.

Salinity measurements made November 15,1979 , during a high tide $(+7.8 \mathrm{ft})$ but with greater Quinault River discharge (about $1,250 \mathrm{ft}^{3} / \mathrm{s}$ at Lake Quinault), showed that the seawater moved only about one-half mile up the river (fig. 5). Measurements made in the deeper pockets in the channel that contained salty water during the August measurements showed no saline water, suggesting that the higher flows of the river following the fall rains had flushed the seawater from these pockets. 


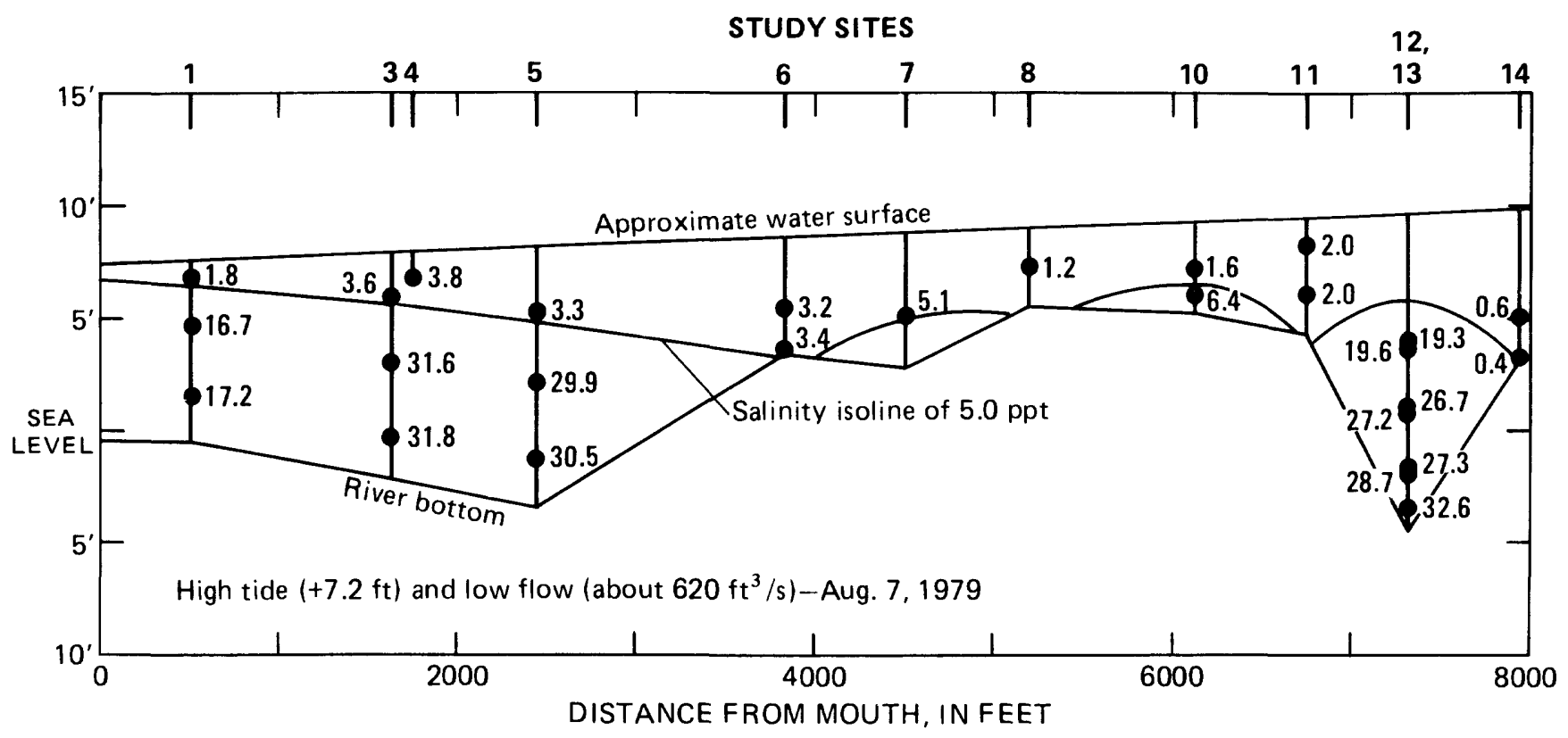

FIGURE 3. - Schematic longitudinal profile of the lower reach of the Quinault River with salinity values during high-tide and low-flow conditions, August 7, 1979.

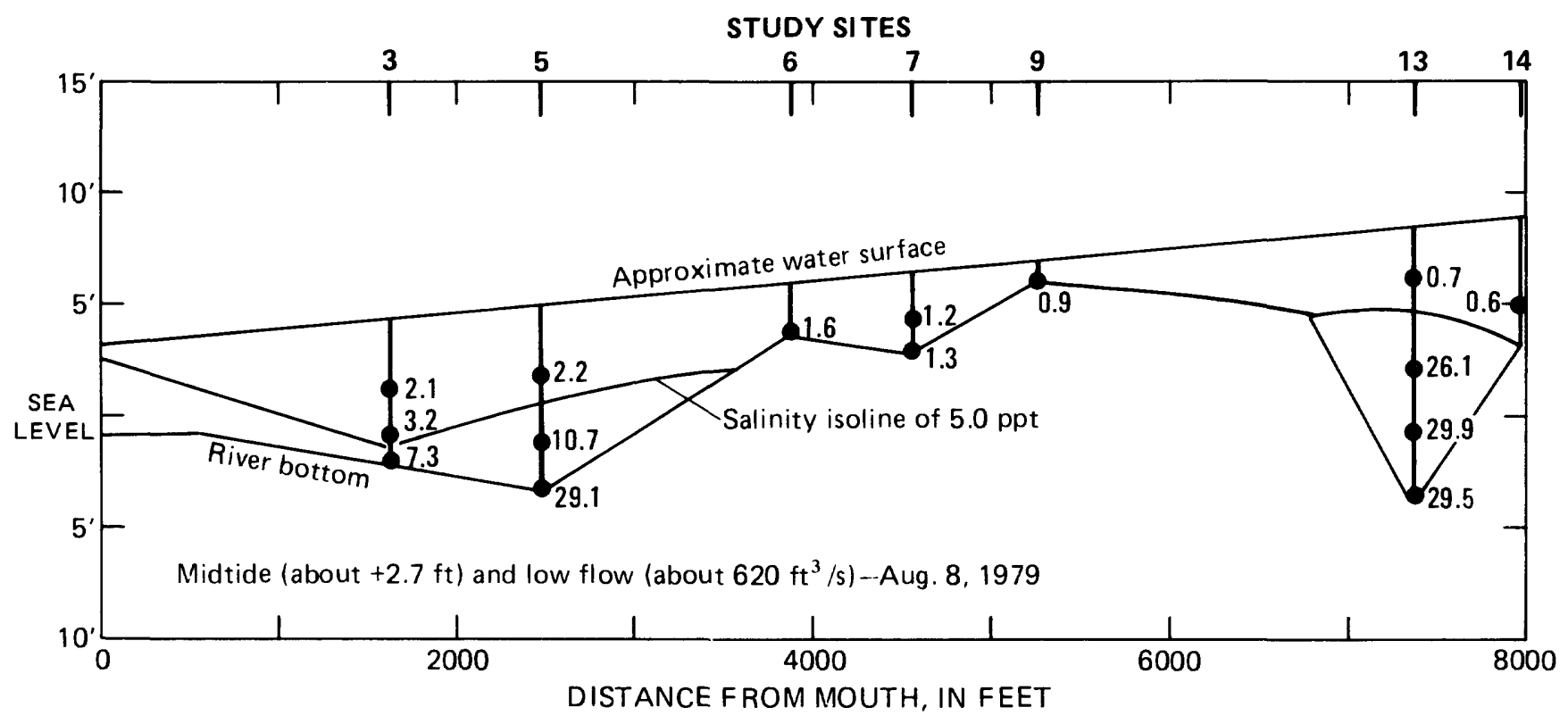

FIGURE 4. - Schematic longitudinal profile of the lower reach of the Quinault River with salinity values during midtide and low-flow conditions, August 8, 1979. 


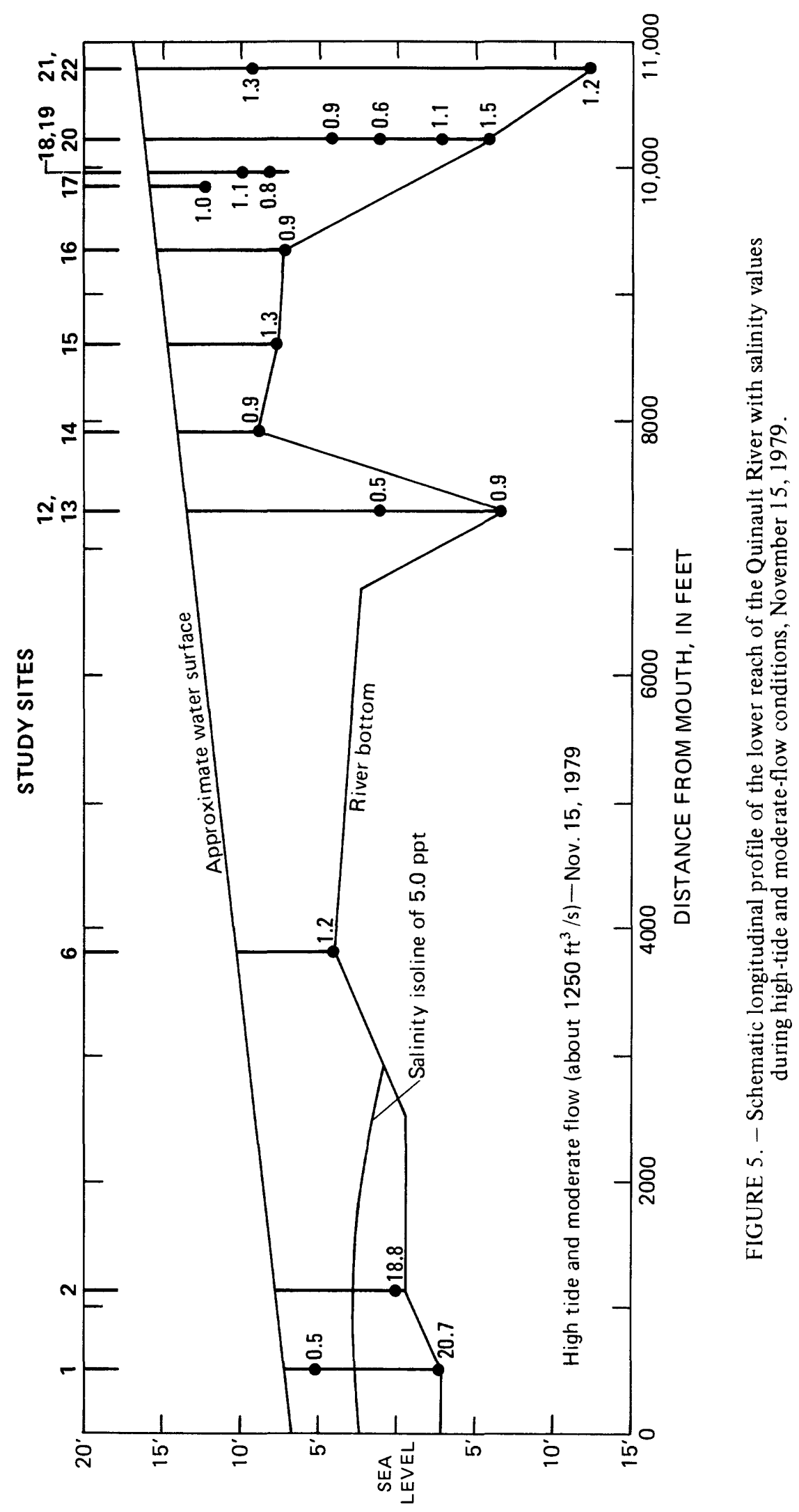


Taholah Water Supply

The community of Taholah has been served many years by a water supply obtained from several closely spaced springs situated about 1 mile southeast of the community (fig. 2). The springs issue at altitudes of approximately $30-80 \mathrm{ft}$ above sea level, from sand and gravel beds overlying the hard blue clay or siltstone of the glacial-drift terrace that rises above the Quinault River. The clay or siltstone dips about 35 degrees to the north of the springs.

The springs have insufficient flow to supply Taholah during the late summer and early fall (Mr. Jeff Jones, Public Works Manager of Taholah, personal commun. 1983). To increase the amount of water available to meet the community's needs, the Tribe drilled two 8-inch diameter wells during March-April 1979. The wells were drilled at an altitude of about $20 \mathrm{ft}$ on the flood plain, about one-half mile east of Taholah and about 75 and $200 \mathrm{ft}$ west of the Quinault River. The wells were drilled near the river to utilize it as a source of recharge to the well field.

The first well (well 21/13-1Cl, also known as "well 1 " or "west well," and shown as $\mathrm{Cl}$ on figure 2) was drilled about $200 \mathrm{ft}$ from the river to a depth of $105 \mathrm{ft}$ and water-bearing zones were encountered from 25 to $31 \mathrm{ft}$ and from 36 to $74 \mathrm{ft}$. Water samples were collected every $10 \mathrm{ft}$ during drilling and were analyzed for specific conductance and for concentrations of iron, manganese, and chloride. Iron and manganese concentrations were high in samples from the upper zones, but decreased with depth; chloride concentrations and specific conductance increased with depth. The water level in well 1 , upon completion, fluctuated in direct response to tidal action in the river. During a bailer test of the well, salty water was noted; consequently, the casing was pulled back to $38 \mathrm{ft}$ and a 100 -slot screen was installed from 38 to $43 \mathrm{ft}$. The casing was later pulled back to $27 \mathrm{ft}$ and the screen installed from 27 to $32 \mathrm{ft}$.

The second well (well 21/13-1C2, also known as "well 2" or "north well," and shown as C2 in figure 2) was drilled about $75 \mathrm{ft}$ from the river to a depth of $28 \mathrm{ft}$ and water-bearing zones were encountered from 18 to $21 \mathrm{ft}$ and 27 to $28 \mathrm{ft}$. No high iron or chloride concentrations were observed. Casing was installed to 23 feet and a 100 -slot screen was installed from 23 to $28 \mathrm{ft}$. Drillers' logs of wells are shown in table 1 at end of report.

During pumping tests of the two wells, on April 13, 1978, water-level drawdowns of less than 1 foot occurred at withdrawal rates of $150 \mathrm{gal} / \mathrm{min}$. However, as test pumping progressed, the water levels in both wells began to rise in response to the rising tide in the river. The water level in well 2 , situated closer to the river, showed a distinct relation to river stage. Measurements showed that a $3.3-\mathrm{ft}$ change in river stage (during a $6.9-\mathrm{ft}$ tide change in the ocean) resulted in a $1.5-\mathrm{ft}$ change in water level. 
Analyses of water samples from the two wells during the pumping tests showed that the water was relatively soft and slightly acidic. The initially high iron and manganese concentrations observed during drilling were no longer present as pumping began, but chloride concentrations were relatively high $(160-185 \mathrm{mg} / \mathrm{L})$.

At the time of the pumping tests, the discharge of the Quinault River (at Lake Quinault) was about $1,700 \mathrm{ft}^{3} / \mathrm{s}$. The deep parts of the river which were observed to be salty during low-flow conditions in August $1979\left(620 \mathrm{ft}^{3} / \mathrm{s}\right)$ probably contained freshwater during the pumping tests.

Calculations made by consulting engineer D. H. Schubert (written commun., 1978), based on the pumping tests of the wells, indicated that the wells had a combined safe pumping rate of $300 \mathrm{gal} / \mathrm{min}$. The radii of influence of the wells after 1 day of pumping at this rate was calculated to be $360 \mathrm{ft}$, or in to the nearby Quinault River. The existence of isolated pockets of salty water in the river was not known at the time of Schubert's calculations. He apparently assumed the presence of only freshwater in the river, and, therefore, predicted that the flow induced from the river by pumping the wells would serve to improve the existing water quality in the well field.

The well field was connected to the Taholah water system and incorporation of the wells into the public system began in June 1978. A salty taste was noticed almost immediately, and testing indicated a high concentration (more than 300 $\mathrm{mg} / \mathrm{L}$ ) of chloride was present in the water system. At this point, the Tribe placed the wells on standby status, returned to the spring system for their water supply, and enlisted the help of the U.S. Geological Survey to determine the source of chloride in the water from the well field. 


\section{Test Drilling}

To determine the nature of the ground-water-flow system at Taholah, 10 test holes were augered at five sites (fig. 2). At each site, shallow (30 to $37 \mathrm{ft}$ ) and deep $(49$ to $85 \mathrm{ft}$ ) holes were augered and piezometers were installed.

After installing the piezometers, the wells were surged (a process in which water is forced in and out of the well screen in order to remove the fine-grained materials around the screen) and slugged (a volume of water is dumped into the well, and the effect on water level is observed) to assure connection with the materials opposite the sand points at the bottom of the wells. Land-surface altitudes were surveyed and water levels were measured in each well (from 2 to 12 times) between September 15, 1979, and January 22, 1980 (table 3). Specific-conductance values were measured in water samples taken from eight of the wells on November 15-16, 1979 , and from seven of the wells on January 21, 1980. Several wells would not yield sufficient water for an adequate sample volume.

In addition to the above wells, four test holes $(21 / 13-1 \mathrm{Jl}, 1 \mathrm{~J} 2,1 \mathrm{~J} 3$, and $21 / 12-6 \mathrm{Ll}$ ) were augered along the upland slope above the Tribal springs as part of a general reconnaissance of ground-water conditions adjacent to Taholah. Four additional test holes (21/12-6E1 and F1, F2, F3) were augered on the valley floor (fig. 2) about three-quarters of a mile upstream from the Tribal well field. These four holes were augered to obtain a general preliminary appraisal of the suitability of the area as an alternative well-field site.

Drillers' logs and well records of the test holes and other wells in and adjacent to Taholah, along with data collected on water levels and specific conductance, are presented in tables 1-3 at end of report. 
Data (table 3 at end of report) collected from the test holes at Taholah on January 21, 1980, were sufficient to supply a general understanding of the ground-water flow system. Figure 6 shows the generalized ground-water flow directions at relatively high tide $(+9.4 \mathrm{ft})$ and at a lower tide $(0.0 \mathrm{ft})$, based on water levels meaured on January $21,1980$.

At low tide, the dominant directions of ground-water flow were from the river on the east, Long Pond on the west, and the upland on the south. Ground water flowed from Taholah northward to the river and westward to the ocean.

At high tide, the flow system was drastically different. The increased water level in the river prevented outflow to the north. Similarly, the higher sea level along the coastline eliminated the outflow to the west. The result was a general mounding of the water table along all margins of Taholah. This cycle of changing ground-water flow directions apparently occurs with each tide cycle.

The inflow of water from the river, at high and low tides, from the east (where deep pockets of salty water often exist) and from the ocean and the river on the west and north during high tides, introduces large quantities of salty water into the ground-water system at Taholah. Water samples collected at high tide from two deep wells ( 40 and $45 \mathrm{ft}$ below sea level) showed specific-conductance values of 2,050 and 3,180 micromhos, respectively (equivalent to chloride concentrations of about 550 and $830 \mathrm{mg} / \mathrm{L}$ ). Four shallow wells had conductance values of 232-466 micromhos (about 75-150 mg/L of chloride). This precludes any chance of obtaining a good-quality water supply from the ground-water system at the town of Taholah. 

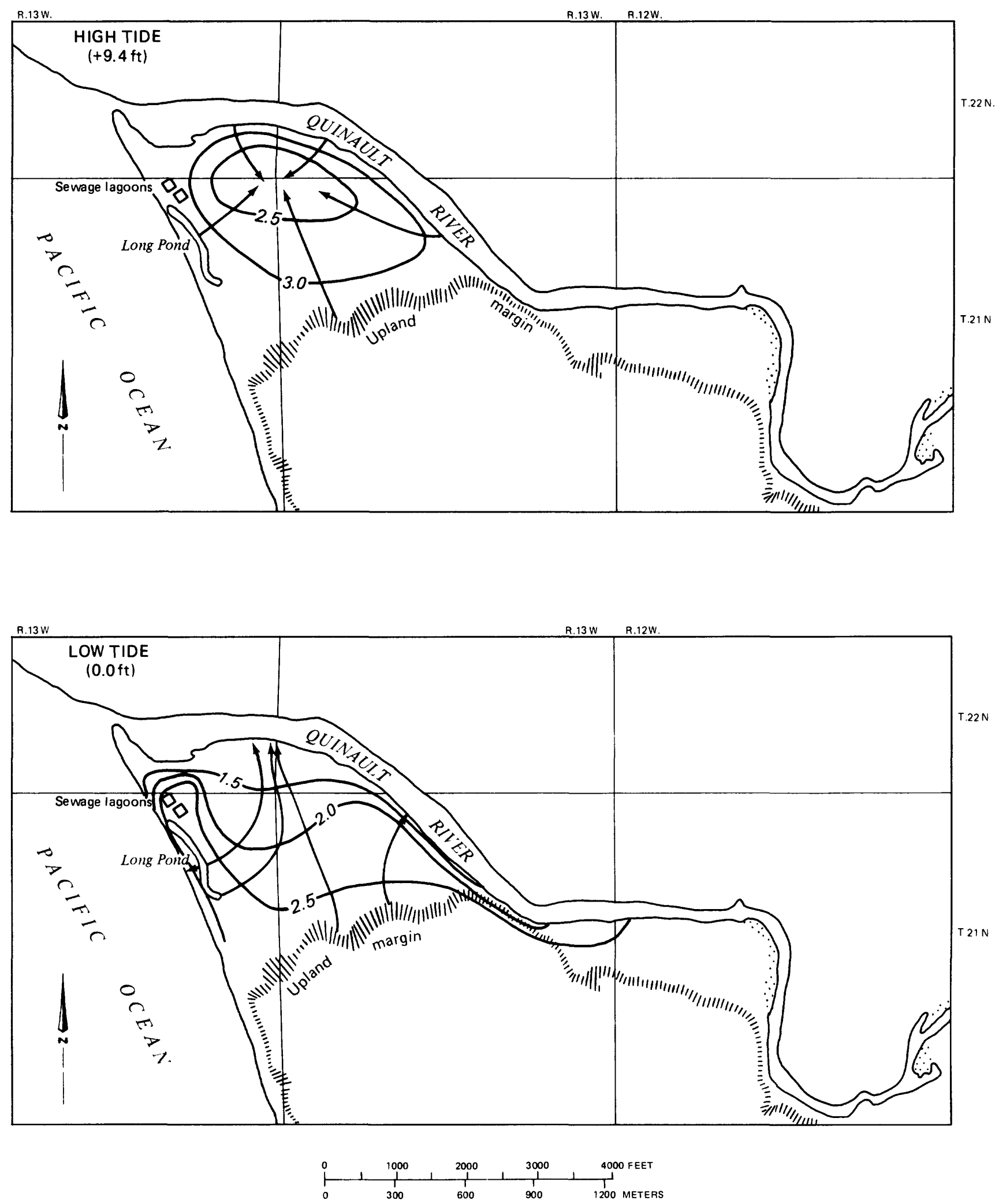

FIGURE 6. - Probable configuration of the water table (contour interval is 0.5 feet above sea level) and generalized ground-water flow directions at Taholah, January 21, 1980. 


\section{RECON NAISSANCE OF GROUND-WATER CONDITIONS IN AREAS ADJACENT TO TAHOLAH}

A reconnaissance of ground-water conditions was made for two areas east of Taholah: (1) the upland terrace, from the water-supply springs to a point about one-half mile east of the springs; and (2) the valley floor east of and below this part of the upland terrace (fig. 2).

Data from the test holes (21/13-1J1, J2, and J3) near the tribal springs indicate that the springs are fed by ground water moving through unconsolidated glacial drift at or near the contact with the underlying Tertiary siltstone. Only a few feet of saturated thickness exists, and most of the flow discharges at the tribal springs. The data also suggest that wells drilled into the glacial drift underlying the upland would not necessarily increase the amount of water already obtained at the tribal springs, and might actually lead to a decrease in springflow. The Tertiary siltstone extends at least several hundred feet below the glacial deposits and probably would not yield significant amounts of water. Data from a test hole (21/12-6L1) located about one-half mile east of the tribal springs indicated that ground-water conditions at this site are virtually the same as at the springs. The tribe drilled a test well to $384 \mathrm{ft}$ in November $1980(21 / 13-1 \mathrm{~J} 4)$ to investigate the Tertiary siltstones. Only insignificant yields of water were encountered in the tribal test well.

Four test holes augered on the valley floor east of the springs $(21 / 12-6 \mathrm{El}$ and F1, F2, and F3) provided inconclusive data. Significant amounts of coarse-grained materials were encountered below river level, but the degree of connection between the river and these materials could not be determined within the limits of this project.

A public supply for Taholah probably could be obtained from wells on the valley floor east of the springs, provided that there is good hydraulic connection with the river and the maximum upstream extent of salty water is downstream from the selected site. In order to properly evaluate the potential water yield and quality at any selected site, additional work needs to be done to determine the hydraulic connection and seawater extent. 
Rau, W. W., 1973, Geology of the Washington coast between Point Grenville and the Hoh River: Washington Division of Geology and Earth Resources Bu1letin 66, 58 p.

----1975, Geologic map of the Destruction Island and Taholah Quadrangles, Washington: Washington Division of Geology and Earth Resources Geologic Map GM-13, one sheet.

U.S. Department of Commerce, 1960-73, C1imatogica1 data, Washington: annua1 summaries.

U.S. National Oceanic and Atmospheric Administration, 1974-78, Climatological data, Washington: annual summaries. 
TABLE 1.--Drillers' 1ogs of wells and test holes in and adjacent to Taholah

\begin{tabular}{ccc}
\hline Material & $\begin{array}{c}\text { Thickness } \\
\text { (feet) }\end{array}$ & $\begin{array}{l}\text { Depth } \\
\text { (feet) }\end{array}$ \\
\hline
\end{tabular}

21/12-6E1. USGS test hole \#9. Augered January 23, 1980.

Altitude $25 \mathrm{ft}$. No casing, hole backfilled.

Sand and clay, brown- 6

Sand, clay, and fine gravel, brown-_-_- $\quad 4 \quad 10$

Grave1 (2-3 inch diameter), clay, and sand--

Sand, brown, with some gravel- $\quad 6 \quad 77$

21/12-6F1. USGS test hole \#8. Augered January 22, 1980.

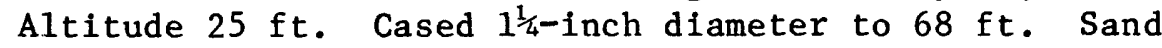
point 68-70 ft, 0.010-inch slot size.

Sand and clay, brown- 6

Sand, clay, and fine gravel, brown-_-_- $\quad 6 \quad 12$

Sand, clay, and coarse gravel- $18 \quad 30$

Sand and gravel (?)- $46 \quad 76$

Clay (?)

21/12-6F2. USGS test hole 非10. Augered January 23, 1980. Altitude $25 \mathrm{ft}$. Cased $1 \frac{1}{4}$-inch diameter to $66.8 \mathrm{ft}$.

Sand point 66.8-68.8 ft, 0.010-inch slot size.

Sand and clay, brown- $13 \quad 13$

Clay, sand, and fine gravel, brown- 53

Gravel (?) $\quad 4 \quad 70$

21/12-6F3. USGS test hole 非11. Augered January 23, 1980. Altitude $25 \mathrm{ft}$. No casing, hole backfilled.

Clay and sand, brown-- 6

Clay, with more sand, brown- $\quad 9 \quad 15$

Gravel, with some clay and sand (?)-_- $\quad 28 \quad 43$

Grave1- $\quad 2845$

? (softer) $\quad 2 \quad 47$ 
TABLE 1.--Drillers' logs of wells and test holes in and adjacent to Taholah--Continued

\begin{tabular}{ccc}
\hline Material & $\begin{array}{c}\text { Thickness } \\
\text { (feet) }\end{array}$ & $\begin{array}{l}\text { Depth } \\
\text { (feet) }\end{array}$ \\
\hline
\end{tabular}

21/12-6L1. USGS test hole \#12. Augered January 24, 1980. Altitude $90 \mathrm{ft}$. No casing, hole backfilled.

Soil sandy and clayey, brownGravel, sand, and clay, brown-_Gravel, sand, and clay, tan-_-_-

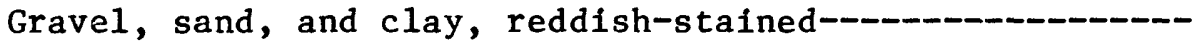
Gravel, sand, and clay, brown-Gravel, with more clay, tan, wet (no significant yield)-Gravel, coarse, dry-Clay, sand, and gravel, gray, wet (no significant yield)Clay and sand, gray, wet (no significant yield)--

$\begin{array}{rr}3 & 3 \\ 7 & 10 \\ 1 & 11 \\ 1 & 12 \\ 6 & 18 \\ 11 & 29 \\ 13 & 42 \\ 14 & 56 \\ 6 & 62\end{array}$

21/12-18K2. W. W. McKee. Drilled by Taylor Drilling Co., May 10, 1968. Altitude $130 \mathrm{ft}$. Cased 10-inch diameter to $50 \mathrm{ft}$. Perforated $30-40 \mathrm{ft}$.

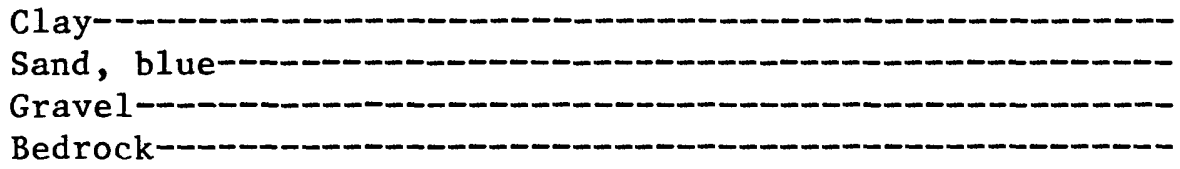

21/12-20F1. Santiago Beach Development Co. Drilled by Taylor Drilling Co., January 28, 1966. Cased 8-inch diameter to $264 \mathrm{ft}$. Perforated 242-252 ft.

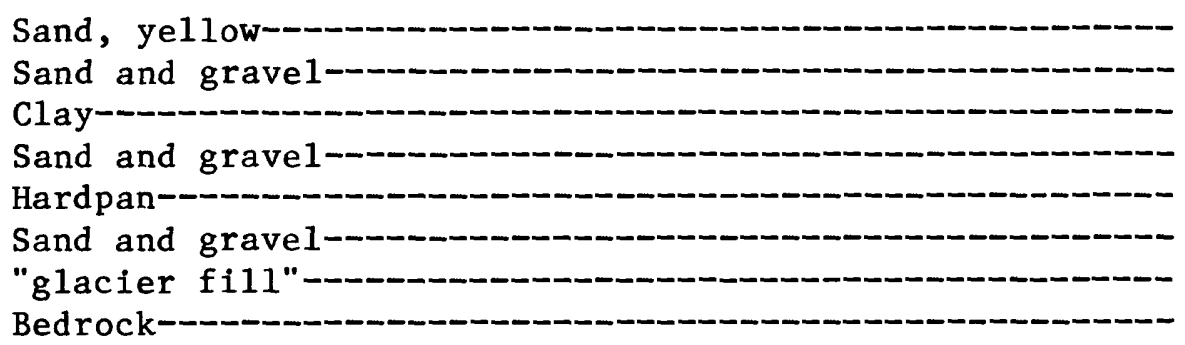

$\begin{array}{rr}91 & 91 \\ 71 & 162 \\ 6 & 168 \\ 53 & 221 \\ 5 & 226 \\ 15 & 241 \\ 23 & 264 \\ \text { at } & 264\end{array}$

21/12-20Q1. Lawrence Axford (?). Drilled by Pete Smith Well Drilling, July 28, 1979. A1titude $100 \mathrm{ft}$. Cased 6-inch diameter to $79 \mathrm{ft}$. Open end.

Sand and clay, brown-Clay, yellow-Clay and gravel, brown-C1ay, ye11ow-

$\begin{array}{rl}70 & 70 \\ 5 & 75 \\ 10 & 85 \\ 5 & 90\end{array}$


TABLE 1.--Drillers' logs of wells and test holes in and adjacent to Taholah--Continued

$\begin{array}{ccc}\text { Material } & \begin{array}{c}\text { Thickness } \\ \text { (feet) }\end{array} & \begin{array}{c}\text { Depth } \\ \text { (feet) }\end{array} \\ \end{array}$

21/13-1C1. Quinault Tribe, "West Well" or "We11 No. 1." Drilled by Stoican Drilling Co., Inc., April 13, 1978 . Altitude $20 \mathrm{ft}$. Cased 8-inch diameter to $27 \mathrm{ft}, 7-i n$. diameter 32-36 ft. Screened 27-32 ft, 0.100-inch slot size.

Clay, sandy, brown--

Clay, gravelly, brown-_-_-_-_-_-

Sand and gravel, brown, water-bearing--_-

Clay, sandy, gravelly, brown, packed--_-

Clay, grave1ly, brown, water-bearing-_-_-_-_-_-_-_-_

Gravel and clay, brown, water-bearing--_-

Gravel and sand, blue, water-bearing, high chloride

concentrations----

Clay, silty, sandy, blue-_-

Clay, gray--

$\begin{array}{rr}9 & 9 \\ 16 & 25 \\ 6 & 31 \\ 5 & 36 \\ 5 & 41 \\ 7 & 48 \\ & \\ 31 & 79 \\ 3 & 82 \\ 23 & 105\end{array}$

21/13-1C2. Quinault Tribe, "North Well" or "Well No. 2." Drilled by Stoican Drilling Co., Inc., April 12, 1978. Altitude $20 \mathrm{ft}$. Cased 8-inch diameter to $23 \mathrm{ft}$. Screened 23-28 ft, 0.100-inch slot size.

Clay, sandy, black and brown-

Gravel and sand, water-bearing--

Clay, gravelly, sandy, hard--

Gravel and sand, packed--

Sand, fine, and gravel, water-bearing--

21/13-1D1. USGS test well 非-deep. Augered

October 1, 1979. Altitude $13.98 \mathrm{ft}$ (top of casing

at $16.98 \mathrm{ft}$ ). Cased $1 \frac{1}{4}-$ inch diameter to $50 \mathrm{ft}$.

Sand point 50-52 ft, 0.010-inch slot size.

Sand and gravel (1-inch diameter)--

Clay, silty, brown---

Sand---

Sand and grave1 (1/2-1 inch diameter)--

Sand, coarse, and gravel, water-bearing starting at

$21 \mathrm{ft}-\cdots$

Gravel (1-3inch diameter), silty-

$\begin{array}{rr}7 & 7 \\ 11 & 18 \\ 3 & 21 \\ 1 & 22 \\ 5 & 27 \\ 1 & 28\end{array}$


TABLE 1.--Drillers' logs of wells and test holes in and adjacent to Taholah--Continued

\section{Material}

Thickness

Depth

(feet)

(feet)

21/13-1D2. USGS test hole 非-shallow. Augered

October 2, 1979. Altitude $14.89 \mathrm{ft}$ (top of casing

at $18.79 \mathrm{ft}$ ). Cased $1 \frac{1}{4}-$ inch diameter to $27.7 \mathrm{ft}$.

Sand point 27.7-30.2 ft, 0.020-inch slot size.

Grave1 (fil1?) (2-3 inch diameter)-

Gravel and clay--

Sand--nor

Sand and some gravel (1-inch diameter)--

Sand and gravel (2-inch diameter)--

Sand and gravel (1-inch diameter)

$\begin{array}{cc}2 & 2 \\ \frac{1}{2} & 2 \frac{1}{2} \\ 10^{\frac{1}{2}} & 12 \frac{1}{2} \\ 5 \frac{1}{2} & 18 \\ 4 & 22 \\ 12 & 34\end{array}$

21/13-1D3. Quinault Tribe soil test. Drilled by

Rittenhouse-Zeman and Assoc., Apri1 4, 1978.

Altitude $11 \mathrm{ft}$. No casing, hole backfilled.

Fill, sand and gravel, clayey, brown--

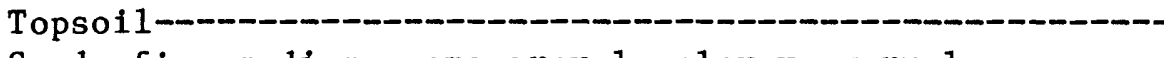

Sand, fine-medium, some gravel, clayey, very loose,

brown, wet--

Sand, fine-medium, brown, wet--

Gravel, fine, sandy, dark brown, wet--

Gravel, silty, sandy, gray, water-bearing-----------

Sand, fine-medium, some coarse sand and silt, gray,

water-bearing-------------

Grave1, sandy, silty, gray, water-bearing----------

$\frac{1}{2} \quad 3 \frac{1}{2}$

$1 \frac{1}{2} \quad 5$

49

$6 \quad 15$

$5 \quad 20$

929

$5 \quad 34$

21/13-1D4. Quinault Tribe soil test. Drilled by

Rittenhouse-Zeman and Assoc., April 4, 1978.

Altitude $16 \mathrm{ft}$. No casing, hole backfilled.

Topsoi1, brown--

Sand, fine-medium, clayey, brown----

Sand, fine-medium, with gravel, gray--

Gravel, fine, sandy, gray, water-bearing--------------

Gravel, fine, with silt, sandy, gray, water-bearing-----

$\begin{array}{rr}2 & 2 \\ 1 & 3 \\ 9 & 12 \\ 14 & 26 \\ 8 & 34\end{array}$


TABLE 1.--Drillers' logs of wells and test holes in and adjacent to Taholah--Continued

\begin{tabular}{ccc}
\hline Material & $\begin{array}{c}\text { Thickness } \\
\text { (feet) }\end{array}$ & $\begin{array}{l}\text { Depth } \\
\text { (feet) }\end{array}$ \\
\hline
\end{tabular}

21/13-1D5. Quinault Tribe school well. Drilled by

Williams Well Drilling Co. Altitude $15 \mathrm{ft}$. Cased

6-inch diameter to $46 \mathrm{ft}$. Screened 46-51 ft,

0.018-inch slot size.

Clay, with a little gravel, yellow-

Sand, with clay, water-bearing--

Sand, water-bearing-

$4 \quad 22$

Grave1, coarse, water-bearing-

$11 \quad 33$

$18 \quad 51$

21/13-1E1. Quinault Tribe ("old" supply wel1).

Drilled by N. C. Jannsen, July 1, 1931.

Altitude $30 \mathrm{ft}$. Originally cased 8-inch diameter

to $202 \mathrm{ft}$. Perforated 10-25 ft, 75-120 ft, and

180-200 ft. Well has been backfilled?

Grave1, cemented-_-

Clay, gray and brown--

Shale (?)

Shale--

Shale, sandy-

Shale----

Rock, black, with shale streaks-_-

Rock, brown, crumbly--

Rock and shale-

Shale--

Shale, brown--

$10 \quad 10$

$37 \quad 47$

$4 \quad 51$

$49 \quad 100$

$27 \quad 127$

$13 \quad 140$

$10 \quad 150$

$4 \quad 154$

$15 \quad 169$

$22 \quad 191$

11202

21/13-1J1. USGS test hole \#7. Augered October 3, 1979. Altitude $104.69 \mathrm{ft}$ (top of casing at $107.69 \mathrm{ft}$ ).

Cased $1 \frac{1}{4}$-inch diameter to $67.2 \mathrm{ft}$. Sand point

67.2-69.2 ft, 0.010-inch slot size.

Silt

Gravel (1-3 inch diameter), with silt, brown--

Gravel, with silt, hard, gray-_-

Gravel (]-inch diameter), sand, some clay--

Silt and fine gravel (1-inch diameter) -

Grave1 (1-2inch diameter), with silt-

Gravel (1-4 inch diameter), with very little silt-------

Gravel (1-inch diameter)--_-

Gravel (1-3 inch diameter), silt, and clay--

Grave1-

$\begin{array}{rr}2 \frac{1}{2} & 2 \frac{1}{2} \\ 4 \frac{1}{2} & 7 \frac{1}{2} \\ 2 & 9 \\ \text { at } & 9 \\ 6 & 15 \\ 7 & 22 \\ 3 & 25 \\ 3 & 28 \\ 44 & 72 \\ \text { at } & 72\end{array}$


TABLE 1.--Drillers' logs of wells and test holes in and adjacent to Taholah--Continued

\begin{tabular}{ccc}
\hline Material & $\begin{array}{c}\text { Thickness } \\
\text { (feet) }\end{array}$ & $\begin{array}{l}\text { Depth } \\
\text { (feet) }\end{array}$ \\
\hline
\end{tabular}

21/13-1J2. USGS test hole 非6A. Augered September 17, 1979. Altitude $85 \mathrm{ft}$. No casing, hole backfilled.

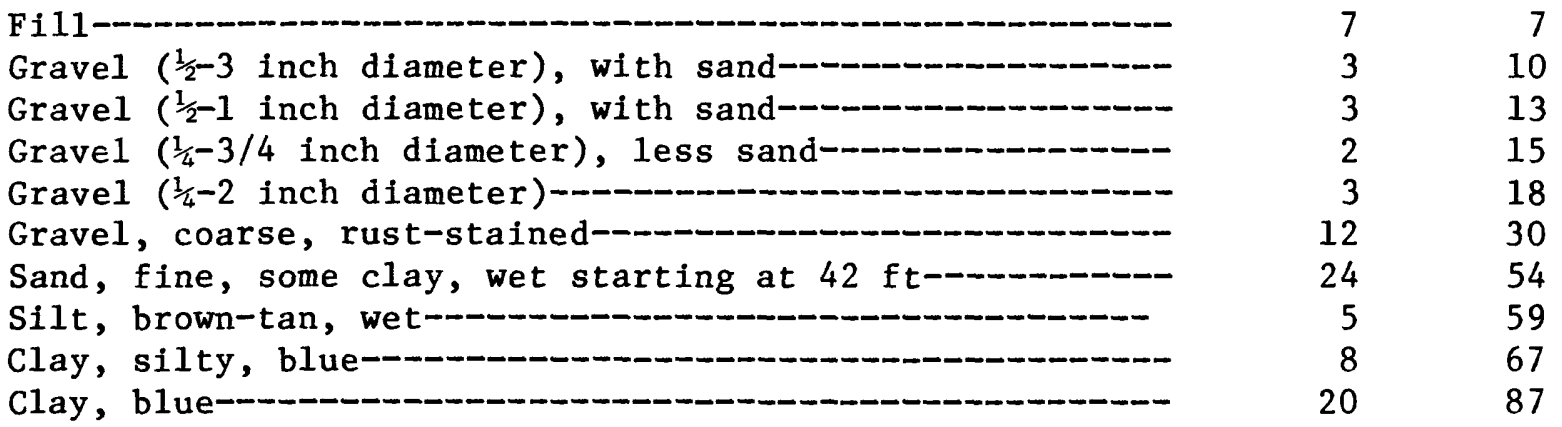

21/13-1J3. USGS test hole \#6B. Augered September 28, 1979. Altitude $85.28 \mathrm{ft}$ (top of casing at $86.08 \mathrm{ft}$ ). Cased $1 \frac{1}{4}$-inch diameter to $54.5 \mathrm{ft}$. Sand point 54.5-57 ft.

Fill-

Gravel ( $\frac{1}{2}-$ inch diameter) and sand-

Gravel ( $\frac{1}{2}-3$ inch diameter)

Gravel (finer) and sand-

Gravel (1-4 inch diameter)

Sand and silt, brown-

Silt, hard-

$\begin{array}{cl}7 & 7 \\ 2 & 9 \\ 12 & 21 \\ 1 \frac{1}{2} & 22 \frac{1}{2} \\ 6 \frac{1}{2} & 29 \\ 21 & 50 \\ 7 & 57\end{array}$

21/13-1J4. Quinault Tribe test well. Drilled by Burt Well Drilling, Inc., July 29, 1980 (to $384 \mathrm{ft}-$ plan to deepen to $600 \mathrm{ft}$ or more). Altitude $105 \mathrm{ft}$. Cased 8-inch diameter to $384 \mathrm{ft}$. Open end.

Hardpan, sandy, brown-

Hardpan, gravelly, brown

Sand and gravel, gray-brown-

Hardpan, gravelly, brown-

Clay, sandy, orange-brown-

Clay, silty, sandy, blue-

Sand and gravel, dirty, orange-brown-

Clay and sand, silty, with some gravel, blue, water-

bearing- $\quad 31 \quad 120$

Clay, sandy, silty, blue-_ $\quad 44 \quad 164$

Clay, silty, sandy, blue, with grave1, water-bearing--- $\quad 15 \quad 179$ 
TABLE 1.--Drillers' logs of wells and test holes in and adjacent to Taholah--Continued

\begin{tabular}{ccc}
\hline Material & $\begin{array}{c}\text { Thickness } \\
\text { (feet) }\end{array}$ & $\begin{array}{c}\text { Depth } \\
\text { (feet) }\end{array}$ \\
\hline
\end{tabular}

\section{1/13-1J4.--Continued}

Clay, silty, sandy, blue-_-

Clay, silty, sandy, blue, with some fine gravel,

water-bearing-_-_-

water-bearing--

$\begin{array}{rr}21 & 255 \\ 2 & 257 \\ 13 & 270 \\ 5 & 275 \\ 23 & 298 \\ 5 & 303 \\ 16 & 319 \\ 3 & 322 \\ 16 & 338 \\ 1 & 339 \\ 14 & 353 \\ 7 & 360 \\ 23 & 383 \\ 1 & 384 \\ \text { at } & 384\end{array}$

Silt, blue, with gravel- with clay-

Clay, silty, blue-_-

Clay, sticky, blue-_-

Clay, silty, blue, with gravel, water-bearing--_------

Clay, silty, blue--

Sand, blue-brown, and pea gravel, water-bearing---_---

Silt and clay, blue-_-_-

Silt, blue, and rock-_-

Silt and clay, blue-_-_-

Silt and clay, blue, with gravel, water-bearing--------

Clay, silty, gray-brown--

Sand, silty, and pea gravel, blue, water-bearing--------

Silt, blue, and siltstone-_-_-

\section{1/13-2A1. USGS test hole 非-deep. Augered}

September 24, 1979. Altitude $12.74 \mathrm{ft}$ (top of casing at $14.74 \mathrm{ft})$. Cased $1^{\frac{1}{4}}$-inch to $82.9 \mathrm{ft}$. Sand point 82.9-84.9 ft, 0.010 slot size.

Sand, brown, and very coarse gravelClay, brown-gray-black, with organic material-_-_-_Gravel and brown sand, wet starting at $12 \mathrm{ft-}$ Sand, gravel, and clay, start water-bearing at $22 \mathrm{ft}$ or above------

Clay and silt--

Clay, silt, and gravel

Sand, fine gravel, and clay, wood chips, wet----

Grave1---

Sand, fine gravel, and clay-

21/13-2A2. USGS test hole \#3-sha1low. Augered September 25, 1979. Altitude $12.42 \mathrm{ft}$ (top of casing at $13.82 \mathrm{ft}$ ). Cased $1 \frac{1}{4}-$ inch diameter to $36.6 \mathrm{ft}$. Sand point 36.6-38.6 ft, 0.010-inch slot size.

Sand, gravel, and clay, brown and gray-Gravel (2-3 inch diameter)-Sand and gravel, water-bearing-

$\begin{array}{rrrr}20 & & 20 \\ 7 & & 27 & \\ 10 & 1 / 5 & 37 & 1 / 5\end{array}$


TABLE 1.--Drillers' logs of wells and test holes in and adjacent to Taholah--Continued

\begin{tabular}{ccc}
\hline Material & $\begin{array}{c}\text { Thickness } \\
\text { (feet) }\end{array}$ & $\begin{array}{l}\text { Depth } \\
\text { (feet) }\end{array}$ \\
\hline
\end{tabular}

21/13-2A3. USGS test hole \#2-deep. Augered September 25, 1979. Altitude $13.74 \mathrm{ft}$ (top of casing at $15.34 \mathrm{ft}$ ). Cased $1 \frac{1}{4}-$ inch diameter to $57.2 \mathrm{ft}$. Sand point 57.2-59.2 ft, 0.010-inch slot size.

Sand and very coarse gravel, brown-Sand, brown, some fine gravel-_. Sand and clay, brown--_Sand and gravel, brown-Sand and gravel, brown, water-bearing-_Gravel, some sand--

$\begin{array}{rr}2 & 2 \\ 3 & 5 \\ 5 & 10 \\ 7 & 17 \\ 14 & 31 \\ 31 & 62\end{array}$

21/13-2A4. USGS test hole \#2-shallow. Augered October 2, 1979. Altitude $13.72 \mathrm{ft}$ (top of casing at $15.97 \mathrm{ft}$ ). Cased $1 \frac{1}{4}$-inch diameter to $27.25 \mathrm{ft}$. Sand point 27.25-29.25 ft, 0.010-inch slot size.

Cobbles---

Sand----

Sand and gravel-_-c-c-c-

Gravel (1-inch diameter) and sand--

Gravel (1-2 inch diameter) and sand--

$\begin{array}{rr}1 & 1 \\ 6 & 7 \\ 10 & 17 \\ 6 & 23 \\ 9 & 32\end{array}$

22/13-35Q1. USGS test hole \#4-deep. Augered September 26, 1979. Altitude $9.64 \mathrm{ft}$ (top of casing at $11.24 \mathrm{ft})$. Cased $1 \frac{1}{4}-$ inch diameter to $47.9 \mathrm{ft}$. Sand point 47.9-49.9 $\mathrm{ft}$.

Grave1--

Silt--

Gravel, coarse, and sand, moist-_-

Gravel (1-3inch diameter) and sand-_-

Gravel (2-3 inch diameter), some sand---

Grave1 (2-4 inch diameter), water-bearing---

Gravel (2-4 inch diameter), and sand, water-bearing-----

$\begin{array}{cc}\frac{1}{2} & 4^{\frac{1}{2}} \\ 3 \frac{1}{2} & 4 \\ \frac{1}{2} & 4^{\frac{1}{2}} \\ 5 \frac{1}{2} & 10 \\ 38 & 48 \\ 7 & 55 \\ 2 & 57\end{array}$

22/13-35Q2. USGS test hole \#4-shallow. Augered October 2, 1979. Altitude $9.72 \mathrm{ft}$ (top of casing at $11.87 \mathrm{ft}$ ). Cased $1 \frac{1}{4}-$ inch diameter to $28 \mathrm{ft}$. Sand point 28-30.5 ft, $0.020-$ inch slot size.

Sand and small pebbles-Gravel (1-4 inch diameter), some sand-Sand and small pebbles-Gravel (1-3 inch diameter) and sand

$\begin{array}{cc}1 & 1 \\ 2 & 3 \\ 4 \frac{1}{2} & 7 \frac{1}{2} \\ 25 \frac{1}{2} & 33\end{array}$


TABLE 1.--Drillers' logs of wells and test holes in and adjacent to Taholah--Continued

\begin{tabular}{ccc}
\hline Material & $\begin{array}{c}\text { Thickness } \\
\text { (feet) }\end{array}$ & $\begin{array}{l}\text { Depth } \\
\text { (feet) }\end{array}$ \\
\hline
\end{tabular}

22/13-35R1. USGS test hole \#1-deep. Augered September 26, 1979. Altitude $13.08 \mathrm{ft}$ (top of casing at $14.98 \mathrm{ft}$ ). Cased $1 \frac{1}{4}-$ inch diameter to $51.5 \mathrm{ft}$. Sand point 51.5-53.5 ft, 0.010-inch slot size.

Sand and grave1, brown--

Sand, some fine gravel, brown--

Sand and coarse gravel, brown--

Grave1, coarse, some sand---

Gravel, finer, some sand-_-

$\begin{array}{cc}2 & 2 \\ 2 & 4 \\ 3 & 7 \\ 40 & 47 \\ 6 \frac{1}{2} & 53 \frac{1}{2}\end{array}$

22/13-35R2. USGS test hole \#1-sha11ow. Augered October 2, 1979. Altitude $12.71 \mathrm{ft}$ (top of casing at $14.96 \mathrm{ft}$ ). Cased $1 \frac{1}{4}$-inch diameter to $29.9 \mathrm{ft}$. Sand point 29.9-32.4 ft, 0.020-inch slot size.

Sand

Sand and gravel (1-inch diameter) 


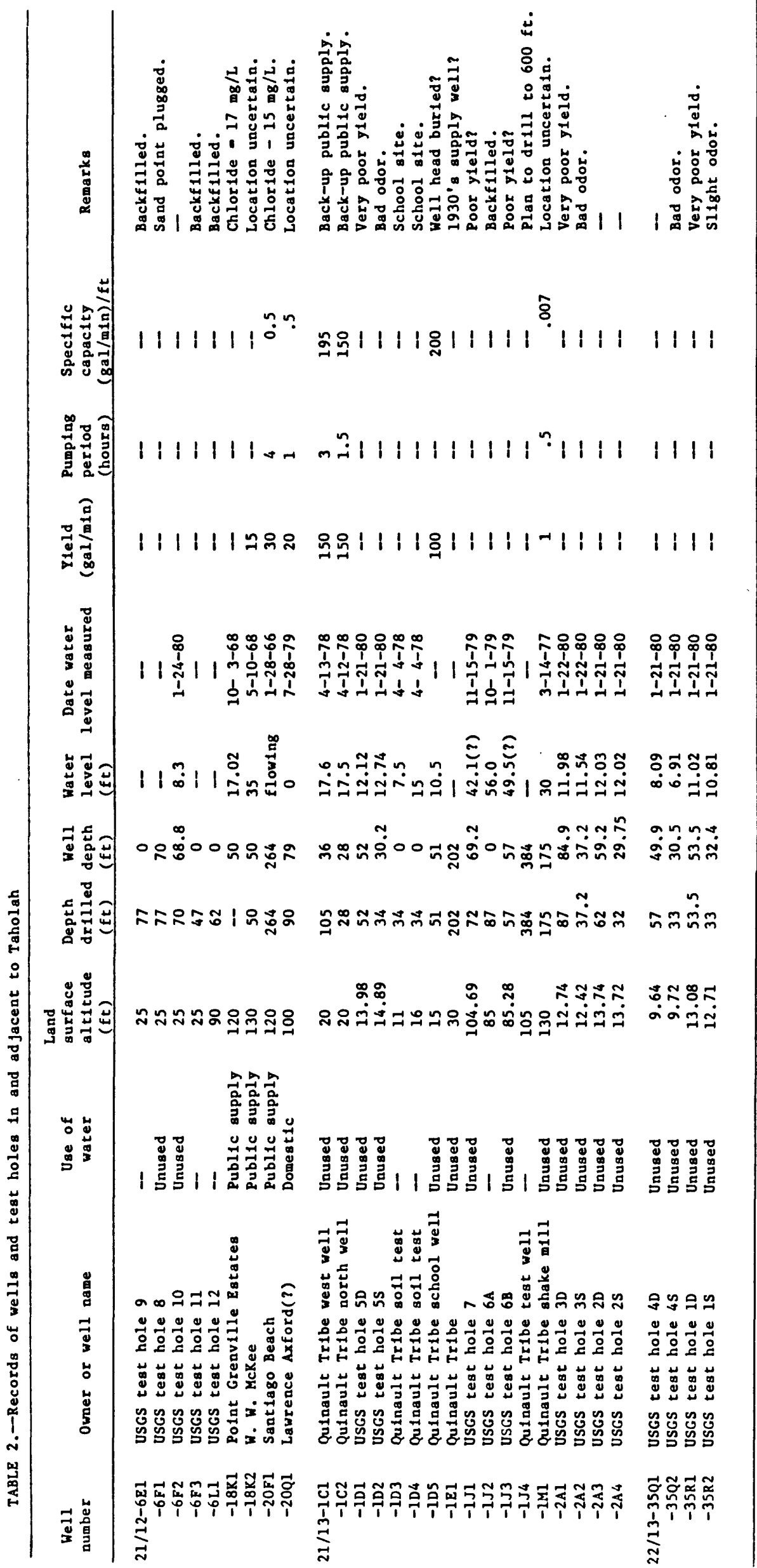


TABLE 3.--Water levels and specific conductances measured in USGS test holes in Taholah

\begin{tabular}{|c|c|c|c|c|c|c|}
\hline $\begin{array}{c}\text { Well } \\
\text { number }\end{array}$ & Date & Time & $\begin{array}{l}\text { Water level } \\
\text { (feet below } \\
\text { land surface) }\end{array}$ & $\begin{array}{l}\text { Water level } \\
\text { altitude } \\
(f t) \\
\end{array}$ & $\begin{array}{c}\text { Specific } \\
\text { conductance }(K) \\
\text { (micromhos) }\end{array}$ & Remarks \\
\hline $21 / 13-1 D 1$ & $\begin{array}{r}10-2-79 \\
11-16-79 \\
1-21-80\end{array}$ & $\begin{array}{r}9: 55 \\
15: 41 \\
12: 30 \\
16: 23\end{array}$ & $\begin{array}{l}14.60 \\
14.66 \\
11: 00 \\
12.12\end{array}$ & $\begin{array}{r}-0.62 \\
-.68 \\
2.98 \\
1.86\end{array}$ & $\overline{\overline{-}}$ & $\begin{array}{l}\text { Sand point appears to be } \\
\text { partially plugged. } \\
\text { This may affect accuracy of } \\
\text { water-level measurements. }\end{array}$ \\
\hline$-1 D 2$ & $\begin{array}{r}10-2-79 \\
11-16-79 \\
1-21-80\end{array}$ & $\begin{array}{l}15: 44 \\
12: 30 \\
16: 21\end{array}$ & $\begin{array}{l}13.80 \\
13.50 \\
12.74\end{array}$ & $\begin{array}{l}1.09 \\
1.39 \\
2.15\end{array}$ & $\begin{array}{l}- \\
370 \\
298\end{array}$ & $\begin{array}{l}\text { K decreased to } 325 \text { after } 5 \mathrm{~m} 1 \mathrm{n} \text {. pumping. } \\
\mathrm{K} \text { decreased to } 261 \text { after } 5 \mathrm{mln} \text {. pumplng. }\end{array}$ \\
\hline$-2 A 1$ & $\begin{array}{r}9-25-79 \\
9-27-79 \\
9-28-79 \\
10-1-79 \\
10-2-79 \\
11-15-79 \\
1-21-80 \\
1-22-80\end{array}$ & $\begin{array}{r}7: 58 \\
12: 15 \\
13: 05 \\
12: 28 \\
12: 35 \\
16: 03 \\
10: 48 \\
15: 50 \\
12: 09 \\
13: 43 \\
9: 44 \\
10: 03\end{array}$ & $\begin{array}{r}12.19 \\
12.00 \\
11.87 \\
11.77 \\
12.56 \\
11.66 \\
11.32 \\
9.52 \\
11.10 \\
10.60 \\
11.97 \\
11.98\end{array}$ & $\begin{array}{l}.55 \\
.74 \\
.87 \\
.97 \\
.18 \\
1.08 \\
1.42 \\
3.22 \\
1.64 \\
2.14 \\
.77 \\
.76\end{array}$ & $\begin{array}{l}\overline{-} \\
\overline{-} \\
\overline{-} \\
\overline{-} \\
\overline{-} \\
\overline{-} \\
-\end{array}$ & $\begin{array}{l}- \\
-- \\
-- \\
-- \\
\text { Sand point appears to be partially } \\
\text { plugged. This may affect accuracy } \\
\text { of water-1evel measurements. } \\
- \\
- \\
- \\
- \\
-\end{array}$ \\
\hline$-2 \mathrm{~A} 2$ & $\begin{array}{r}9-25-79 \\
9-26-79 \\
9-27-79 \\
9-28-79 \\
10-1-79 \\
10-2-79 \\
11-15-79 \\
1-21-80 \\
1-22-80\end{array}$ & $\begin{array}{r}12: 14 \\
8: 55 \\
13: 05 \\
12: 25 \\
12: 30 \\
16: 07 \\
10: 50 \\
15: 51 \\
9: 46 \\
13: 41 \\
9: 46 \\
10: 04\end{array}$ & $\begin{array}{l}11.80 \\
11.70 \\
11.60 \\
11.20 \\
11.43 \\
11.41 \\
11.18 \\
11.29 \\
11.06 \\
10.20 \\
11.54 \\
11.58\end{array}$ & $\begin{array}{r}.62 \\
.72 \\
.82 \\
1.22 \\
.99 \\
1.01 \\
1.24 \\
1.13 \\
1.36 \\
2.22 \\
.88 \\
.84\end{array}$ & $\begin{array}{l}-- \\
\overline{-} \\
\overline{-} \\
\overline{-} \\
\overline{-} \\
\overline{300} \\
258 \\
\overline{-}\end{array}$ & $\begin{array}{l}-- \\
-- \\
=- \\
=- \\
- \\
-- \\
-- \\
--\end{array}$ \\
\hline $22 / 13-35 Q 1$ & $\begin{array}{r}9-28-79 \\
10-1-79 \\
10-2-79 \\
11-16-79 \\
1-21-80\end{array}$ & $\begin{array}{r}12: 43 \\
12: 22 \\
15.50 \\
10: 30 \\
15: 15 \\
8: 45 \\
15: 51\end{array}$ & $\begin{array}{l}5.66 \\
8.35 \\
8.37 \\
8.40 \\
8.40 \\
7.80 \\
8.09\end{array}$ & $\begin{array}{l}3.98 \\
1.29 \\
1.27 \\
1.24 \\
1.24 \\
1.84 \\
1.55\end{array}$ & $\begin{array}{r}-- \\
-- \\
-- \\
1,000 \\
2,080\end{array}$ & $\begin{array}{l}-- \\
\overline{--} \\
-- \\
-- \\
\bar{k} \text { decreased to } 2,050 \text { after } 5 \mathrm{~min} \text {. pumping. }\end{array}$ \\
\hline $\begin{array}{l}-35 Q 2 \\
-35 R 1\end{array}$ & $\begin{array}{r}11-16-79 \\
1-21-80 \\
9-28-79 \\
10-1-79 \\
10-2-79 \\
11-15-79 \\
1-21-80\end{array}$ & $\begin{array}{r}8: 45 \\
15: 50 \\
12: 38 \\
12: 27 \\
15: 55 \\
10: 80 \\
14: 00 \\
15: 11\end{array}$ & $\begin{array}{r}7.20 \\
6.91 \\
12.78 \\
12.40 \\
12.56 \\
12.02 \\
12.00 \\
11.02\end{array}$ & $\begin{array}{r}2.52 \\
2.81 \\
.30 \\
.68 \\
.52 \\
.86 \\
1.08 \\
2.06\end{array}$ & $\begin{array}{l}720 \\
491 \\
-- \\
=- \\
= \\
= \\
-\end{array}$ & $\begin{array}{l}\text { K decreased to } 466 \text { after } 5 \mathrm{~min} \text {. pumping. } \\
= \\
= \\
= \\
= \\
- \\
-\end{array}$ \\
\hline$-35 R 2$ & $\begin{array}{r}11-15-79 \\
1-21-80\end{array}$ & $\begin{array}{l}14: 00 \\
15: 09\end{array}$ & $\begin{array}{l}11.80 \\
10.81\end{array}$ & $\begin{array}{r}.91 \\
1.90\end{array}$ & $=$ & -- \\
\hline
\end{tabular}

